\title{
Using Isotopic Data to Evaluate Esox lucius (Linnaeus, 1758) Natal Origins in a Hydrologically Complex River Basin
}

\author{
Ryan M. Fitzpatrick ${ }^{1, *(D)}$, Dana L. Winkelman ${ }^{2}$ iD and Brett M. Johnson $^{3}$ (D) \\ 1 Colorado Parks and Wildlife, 317 West Prospect Rd., Fort Collins, CO 80526, USA \\ 2 U.S. Geological Survey, Colorado Cooperative Fish and Wildlife Research Unity, 1484 Campus Delivery, \\ Fort Collins, CO 80523, USA; dana.winkelman@colostate.edu \\ 3 Department of Fish, Wildlife, and Conservation Biology, 1474 Campus Delivery, Colorado State University, \\ Fort Collins, CO 80523, USA; brett.johnson@colostate.edu \\ * Correspondence: ryan.fitzpatrick@state.co.us; Tel.: +1-970-472-4336
}

check for updates

Citation: Fitzpatrick, R.M.; Winkelman, D.L.; Johnson, B.M. Using Isotopic Data to Evaluate Esox lucius (Linnaeus, 1758) Natal Origins in a Hydrologically Complex River Basin. Fishes 2021, 6, 67. https:// doi.org/10.3390/fishes6040067

Academic Editor: Rafael Miranda

Received: 5 October 2021

Accepted: 10 November 2021

Published: 22 November 2021

Publisher's Note: MDPI stays neutral with regard to jurisdictional claims in published maps and institutional affiliations.

Copyright: (c) 2021 by the authors. Licensee MDPI, Basel, Switzerland. This article is an open access article distributed under the terms and conditions of the Creative Commons Attribution (CC BY) license (https:/ / creativecommons.org/licenses/by/ $4.0 /)$.

\begin{abstract}
Otolith microchemistry has emerged as a powerful technique with which to identify the natal origins of fishes, but it relies on differences in underlying geology that may occur over large spatial scales. An examination of how small a spatial scale on which this technique can be implemented, especially in water bodies that share a large proportion of their flow, would be useful for guiding aquatic invasive species control efforts. We examined trace isotopic signatures in northern pike (Esox lucius) otoliths to estimate their provenance between two reservoirs in the Upper Yampa River Basin, Colorado, USA. This is a challenging study area as these reservoirs are only 11-rkm apart on the same river and thus share a high proportion of their inflow. We found that three isotopes $\left({ }^{86} \mathrm{Sr}\right.$, ${ }^{137} \mathrm{Ba}$, and ${ }^{55} \mathrm{Mn}$ ) were useful in discriminating between these reservoirs, but their signatures varied annually, and the values overlapped. Strontium isotope ratios $\left({ }^{87} \mathrm{Sr} /{ }^{86} \mathrm{Sr}\right)$ were different between sites and relatively stable across three years, which made them an ideal marker for determining northern pike provenance. Our study demonstrates the usefulness of otolith microchemistry for natal origin determination within the same river over a relatively small spatial scale when there are geologic differences between sites, especially geologic differences underlying tributaries between sites.
\end{abstract}

Keywords: conservation; isotopic signature; non-native species control; northern pike; otolith microchemistry; Yampa River; Colorado; USA

\section{Introduction}

Invasive species can have a strong negative influence on aquatic communities, and invasive piscivores are a contributing factor in the decline of native fish populations worldwide [1-3]. The control of nonnative species is critical for conservation, and piscivore management typically focuses on the system-wide removal of nonnative fishes accompanied by management efforts to reintroduce or enhance populations of those that are native [4,5]. However, controlling established nonnative piscivores is problematic and is frequently unsuccessful $[2,6,7]$. Ultimately, the success or failure of removal efforts depends on the probability of reinvasion and an understanding of the sources of established nonnative piscivores.

Determining natal origins by traditional means can be challenging due to problems associated with marking and recapturing juvenile fish [8]. For instance, mechanical marking techniques are usually not appropriate for small juvenile fish and mechanical marks can be lost [9]. However, it is well known that analyses of isotopic concentrations in calcified structures can be reliably used to discriminate among fish that have spawned in different water bodies [10-12]. Otoliths are calcified structures in fish that are important for balance and hearing [13-15]. The microstructure of otoliths can be used to examine the age and growth of fishes [16-18], and the size and shape of otoliths are associated with environmental and population characteristics, which can be a diagnostic tool to discriminate fish from 
different geographical areas [19-22]. Otolith microchemistry has been used to estimate the provenance of several fish species in freshwater [23-26], movements between fresh and saltwater [27-29], and hatchery versus natural production [30]. It has also been shown to be a useful technique in the Rocky Mountain region for evaluating fish movement and origin [31-34]. The advantage of using otolith isotopic composition is that each fish in the population develops a signature unique to its natal geographical location that is retained for life. Therefore, in large populations with several suspected sources, each individual's hatch location can potentially be identified.

Otolith microchemistry has the highest probability of success when used over a large geographic scale with different sources of water. For example, Gibson-Reinemer et al. [31] used this technique to provide elemental "fingerprints" of hatcheries across Colorado. However, none of these sites were in close spatial proximity, and their water sources could be either surface flows or pumped from an aquifer. Isotopes most frequently used in these analyses include strontium $\left({ }^{86} \mathrm{Sr}\right)$, barium $\left({ }^{137} \mathrm{Ba}\right)$, and manganese $\left({ }^{55} \mathrm{Mn}\right)$, which have been shown to derive from geologic sources $[22,23,35]$. Other isotopes have also been used, but care must be taken in the selection of isotopes. For example, sodium $\left({ }^{23} \mathrm{Na}\right)$ has potential contamination concerns, and zinc $\left({ }^{66} \mathrm{Zn}\right)$ has been linked to diet rather than waterborne sources [36]. Isotopic analyses often use strontium isotope ratios. For example, Wolff et al. [34] examined ${ }^{87} \mathrm{Sr} /{ }^{86} \mathrm{Sr}$ isotopes in the Yampa River (Colorado, USA), but that study had just five samples from the two reservoirs included in this study (Lake Catamount and Stagecoach Reservoir) and they were collected in only one year, so they were not able to examine temporal variation in these signatures. However, Wolff et al. [34] was able to demonstrate the usefulness of isotopic ratio data on a large spatial scale, in this case the Upper Colorado River Basin, USA, with multiple fish species. The isotopic signatures were unique among reservoirs and overlapped among species [34].

To obtain finer-scale information, spatial heterogeneity and temporal variation in environmental signatures must be quantified $[37,38]$. If temporal variation in signatures is detected, resource-intensive efforts would be required to collect fish annually to build a bank of elemental signatures to identify multiple age classes of fishes. Ciepiela and Walters [38] demonstrated the utility of strontium isotopic ratios $\left({ }^{87} \mathrm{Sr} /{ }^{89} \mathrm{Sr}\right)$ within a basin, but were not able to differentiate sites within a single stream. Small spatial scale applications and the temporal variability of isotopic ratios need to be evaluated, particularly for water bodies that share a high proportion of their flow. Although application of otolith microchemistry is challenging, for example, temperature, salinity, diet, and physiological stress may affect otolith microchemistry [36,39-42], it can be a powerful tool for estimating the origins of fishes.

Northern pike (Esox lucius) are a widespread nonnative piscivore that are responsible for reductions in native fish populations, especially in the arid western United States [43-45]. Northern pike are not native in the Colorado River Basin and are a major predatory threat to four U.S. federally listed species: the Colorado pikeminnow (Ptychocheilus lucius), humpback chub (Gila cypha), razorback sucker (Xyrauchen texanus), and the bonytail (Gila elegans) [46,47]. Johnson et al. [48] estimated that northern pike consumed more fish on a per-capita basis than any other fish species in the Yampa River. Control efforts for northern pike are ongoing in the Yampa River, which would benefit from more information regarding sources of recruitment [47,49]. The Yampa River is located in northwest Colorado and flows primarily to the west from its headwaters in the Flat Tops Wilderness to the Green River near the Colorado/Utah border (Figure 1a). Geologic composition underlying the Yampa River is diverse (Figure 1b), and this may be reflected in water chemistry which ultimately affects the chemical composition of fish otoliths [50-52]. It is largely free flowing, with extreme changes in flow being driven by snowmelt [50]. Flows generally begin increasing in April, with maximum flows in May and June, and then decreasing flows beginning in July. Northern pike were stocked in Elkhead Reservoir (which is $98 \mathrm{rkm}$ downstream of Lake Catamount in the Yampa River Basin) in 1977 and likely escaped into the Yampa River from the reservoir in the late 1970s [54]. Subsequently, 
they spread throughout the Yampa River as there was no barrier in place after the dam was built. However, an outlet screen and spillway net have since been added to prevent escapement [55]. Two reservoirs in the upper Yampa River have established populations of northern pike: Stagecoach Reservoir and Lake Catamount. Dam construction on Lake Catamount was completed in 1978 and Stagecoach Reservoir was constructed in 1989. Northern pike were first detected in Stagecoach Reservoir in 1994, potentially from an illicit introduction, and then in Lake Catamount in 1995, likely as escapees from Stagecoach Reservoir [49]. Escapement is more likely than illicit introduction for Lake Catamount because this is a private reservoir closed to public access and the priority of the lake's management is a rainbow trout (Oncorhynchus mykiss) fishery, to which an illicit northern pike introduction would be detrimental. The Lake Catamount dam is a complete barrier to upstream fish movement, so the establishment of these populations is not likely from upstream movement of the initial stocking into Elkhead Reservoir.

Stagecoach Reservoir and Lake Catamount are both located on the mainstem Yampa River and are separated by 11 rkm (Figure 1a). Stagecoach Reservoir is 316 ha with a mean depth of $13 \mathrm{~m}$ and has a substantial amount of seasonally inundated terrestrial vegetation that northern pike can use for spawning [56]. Lake Catamount is 228 ha with a mean depth of $4 \mathrm{~m}$. The southern portion of Lake Catamount is relatively shallow with extensive vegetation, making it a highly productive northern pike habitat. These reservoirs are likely major sources of northern pike recruitment into the Yampa River, and northern pike eradication efforts are ongoing in Lake Catamount and other areas in the Upper Colorado River Basin [56-58]. Active control efforts have not been enacted on Stagecoach Reservoir because it is logistically infeasible. Therefore, Stagecoach Reservoir will likely remain a source of northern pike recruitment to Lake Catamount and the Yampa River for at least the near future. A clearer understanding of northern pike recruitment dynamics and sources would help control efforts in the basin.

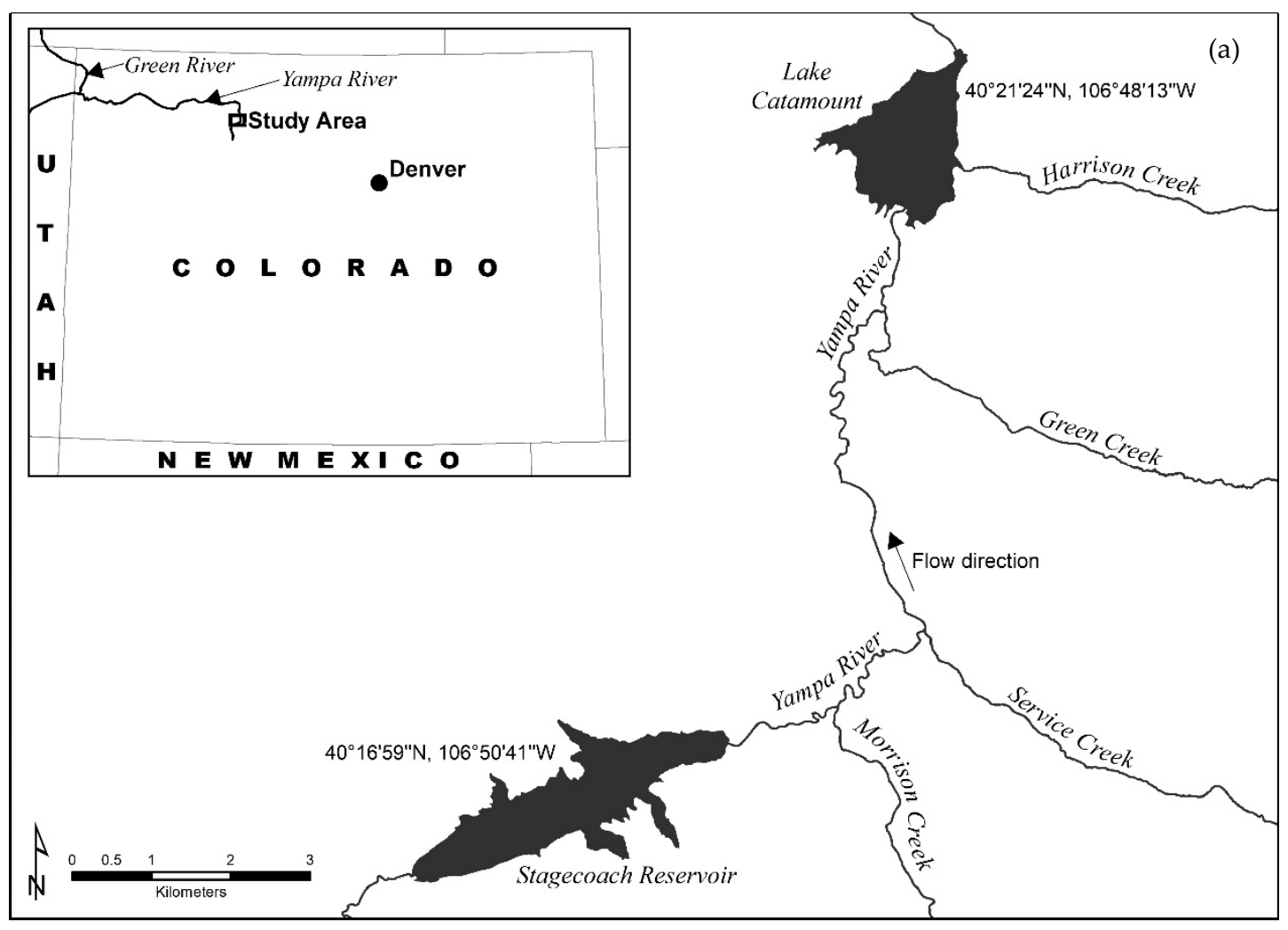

Figure 1. Cont. 


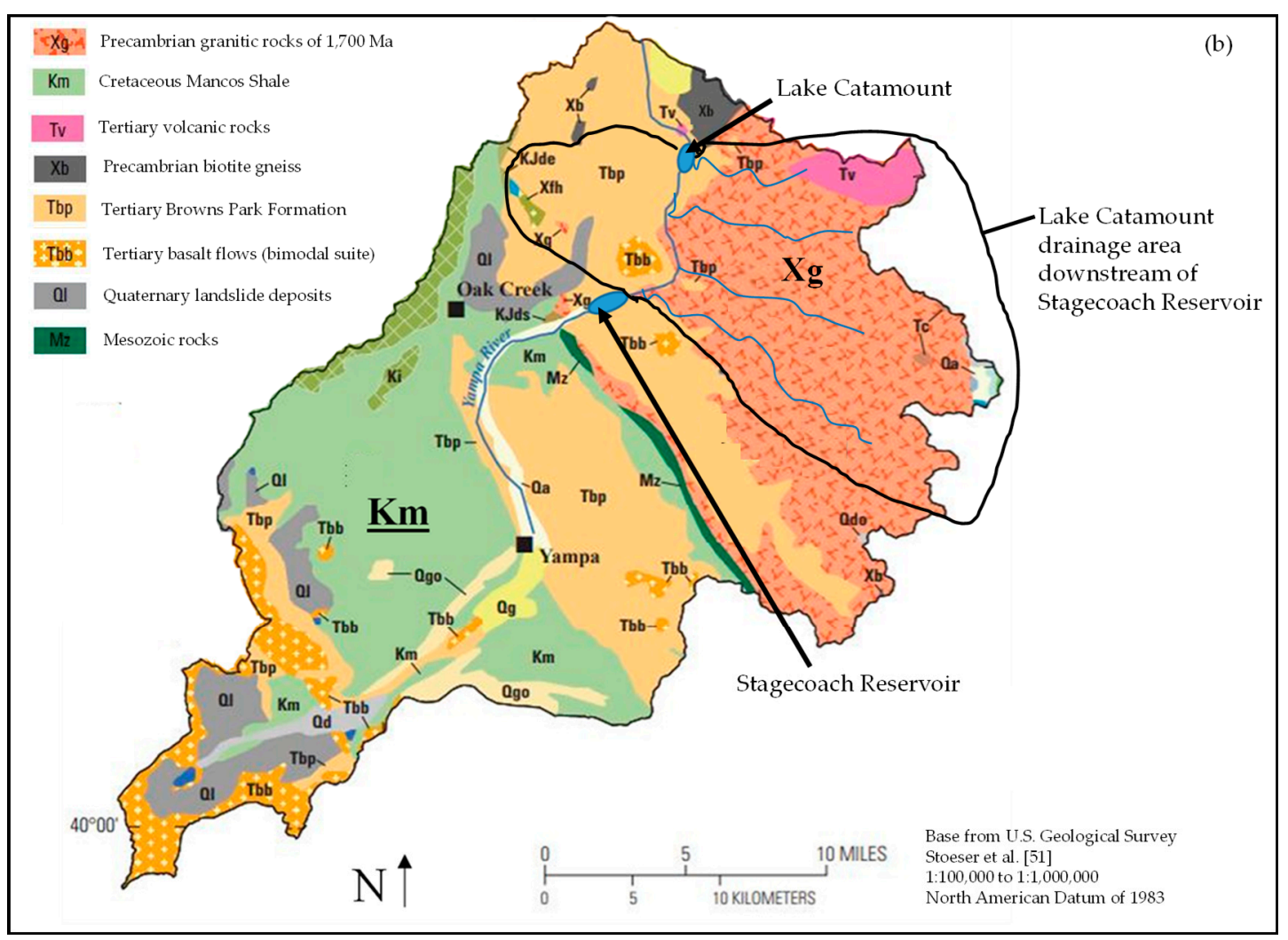

Figure 1. The study area (a) was located in northwest Colorado, USA between Stagecoach Reservoir and Lake Catamount. Geological differences (b) in the upper Yampa River Basin, Colorado (revised from Bauch et al. [50]). The Yampa River flows north from Stagecoach Reservoir to Lake Catamount. The high gradient tributaries that flow from the east into Lake Catamount and into the Yampa River between Stagecoach Reservoir and Lake Catamount have an underlying geology of Precambrian granite rocks of $1700 \mathrm{Ma}$ (red area labeled $\mathrm{Xg}$ ). The area south of Stagecoach Reservoir has lower gradient tributaries that flow over Cretaceous Mancos Shale (green area labeled $\mathrm{Km}$ ). Definitions of other colors and abbreviations are provided in Bauch et al. [50]. Base map obtained from Stoeser et al. [53].

The purpose of our study was to examine the usefulness of isotopic data derived from otolith microchemistry to inform us of the natal origins of northern pike in the Upper Yampa River, Colorado. The specific objectives of our study were to (1) compare isotopic signatures from two reservoirs in the Upper Yampa River that are potential sources of northern pike recruitment in the Yampa River and (2) estimate temporal variation in isotopic data.

\section{Materials and Methods}

\subsection{Otolith Collection and Processing}

Age-0 northern pike were collected using either boat electrofishing or seines. We assumed that age- 0 northern pike collected in our study were captured in the reservoir in which they hatched, and we believe that this is a reasonable assumption for the following reasons. To become entrained in dam releases, age- 0 northern pike would have to move long distances through unsuitable habitats, which is unlikely as it is known that age0 northern pike remain near vegetation for protection and food [59]. Given that Lake Catamount lies downstream of Stagecoach Reservoir, age- 0 northern pike could potentially emigrate from Stagecoach Reservoir into Lake Catamount. Therefore, fish collected in Lake Catamount that were classified as Stagecoach Reservoir may have originated from Stagecoach Reservoir. However, tagging evidence suggests that the emigration of even larger pike from Stagecoach Reservoir to Lake Catamount is rare. Orabutt [56] floy-tagged 864 northern pike $>250 \mathrm{~mm}$ in total length in Stagecoach Reservoir, yet only one tagged fish was reportedly recaptured in Lake Catamount despite intense sampling efforts, and 
even that record was suspect due to the unrealistic estimated growth rate [60]. In addition, the Yampa River between the reservoirs has a relatively high gradient and trout dominate the fish assemblage, including the piscivorous brown trout (Salmo trutta). A lacustrine species such as northern pike would be vulnerable to predation by larger-bodied trout known to inhabit the river between the two reservoirs, further decreasing the probability that a recently hatched pike would make it from Stagecoach Reservoir to Lake Catamount in the short time between hatching and when collections were made. Due to the biology of age-0 northern pike, the small size of fish used in this study, and the physical characteristics of our study sites, we think that age- 0 movement between sites was minimal.

Northern pike were placed individually in plastic storage bags, stored on ice, and transported to the Colorado Cooperative Fish and Wildlife Research Laboratory in Fort Collins, Colorado, USA, where they were stored frozen until otoliths were removed. Plastic utensils and working surfaces were used to reduce the risk of metal contamination. The workspace and all utensils were cleaned with diluted nitric acid (10:1) before removing otoliths and before fish from another location were processed. Otoliths were placed in a Petri dish with distilled water to remove remaining tissue, dried on a paper towel, and placed into a labeled $10 \mathrm{~mL}$ plastic centrifuge tube and stored in an envelope. Otolith preparation for geochemical analysis followed the protocols set forth in Whitledge et al. [61].

Isotopic concentrations of otoliths was analyzed using Laser Ablation Inductively Coupled Plasma Mass Spectrometry (LA-ICP-MS) at the U.S. Geological Survey (USGS) laboratory in Lakewood, Colorado, USA, using a Perkin Elmer ALAN6000 ICP-MS and a CETAC Technologies LSX-5 laser system with a $25 \mu \mathrm{m}$ spot size, $10 \mathrm{HZ}$ pulse frequency, and 8-9 J energy. The particles ablated during the analyses were entrained in a carrier gas (Ar) and transported directly to the ICP-MS. With the use of standard reference materials specifically designed for in situ analyses (e.g., Wilson et al. [62]), the raw LA-ICP-MS data could be converted to quantitative concentrations. The raw signals were qualitatively evaluated for distinct changes in elemental response. Once the integration area was selected, data were converted to concentration using the methods of Longerich et al. [63]. Calcium $\left(40 \%\right.$ in $\left.\mathrm{CaCO}_{3}\right)$ was used as the internal standard (USGS calcium carbonate reference material MACS-1). Drift was monitored using periodic analyses with MACS-1. Internal detection limits were $4.9034 \mathrm{ppm}$ for ${ }^{86} \mathrm{Sr}, 1.870 \mathrm{ppm}$ for ${ }^{137} \mathrm{Ba}$, and $1.3682 \mathrm{ppm}$ for ${ }^{55} \mathrm{Mn}$. No indications of vaterite were observed, so we were confident that the otoliths consisted of aragonite and that the elemental concentrations reflected those in the environment [64].

The isotopic ratios of the otoliths were analyzed at the Woods Hole Oceanographic Institution Plasma Mass Spectrometry Facility, Woods Hole, Massachusetts, USA, using a Thermo Finigan Neptune multicollector ICP-MS coupled with a New Wave Research UP $193 \mathrm{~nm}$ excimer laser ablation system. The laser was configured to run at $80 \%$ intensity, $10 \mathrm{~Hz}$ pulse rate, $35 \mu \mathrm{m}$ laser beam spot size, $5 \mu \mathrm{m}$ per second laser scan speed, and $550 \mu \mathrm{m}$ laser ablation distance. Data normalization and standardization followed the protocol set forth in Wolff et al. [34]. Otoliths and standards were normalized to a daily mean of the National Institute of Standards and Technology (NIST) standard reference material 987 (SRM 987; accepted ${ }^{87} \mathrm{Sr} /{ }^{86} \mathrm{SR}$ of 0.71024$)$ using the following formula: ${ }^{87} \mathrm{Sr} /{ }^{86} \mathrm{Sr}_{\text {normalized }}$ $=(0.71024 \div \mathrm{SRM} 987$ measured $) \times{ }^{87} \mathrm{Sr} /{ }^{86} \mathrm{Sr}_{\text {sample }}$ [34]. Dissolved otolith certified reference material (CRM, [65]; accepted ${ }^{87} \mathrm{Sr} /{ }^{86} \mathrm{Sr}$ of 0.70918); and SRM 987 produced daily mean $( \pm 1 \text { standard deviation, SD; sample size })^{87} \mathrm{Sr} /{ }^{86} \mathrm{Sr}$ of $0.70916( \pm 0.00001 ; n=5)$, and 0.71029 $( \pm 0.00006)$, respectively, and ablations of marine sclerosponge produced a daily mean ${ }^{87} \mathrm{SR} /{ }^{86} \mathrm{Sr}$ of $0.70918( \pm 0.00003 ; n=4)$ [34].

\subsection{Statistical Methods}

The concentrations of three isotopes, strontium $\left({ }^{86} \mathrm{Sr}\right)$, barium $\left({ }^{137} \mathrm{Ba}\right)$, and manganese $\left({ }^{55} \mathrm{Mn}\right)$, were analyzed using a nonlinear Discriminant Function Analysis (DFA). A nonlinear analysis was performed to accommodate differences in sample sizes between locations and potential differences in the variation of the isotopic signatures [66]. We examined classification accuracy using reclassification to avoid an individual fish's isotopic signature 
affecting the discriminant function (DF). Assumptions of the DFA include multivariate normality, testing for multivariate outliers, and homogeneity of variances and covariances [67]. Otolith isotopic concentrations were $\log _{10}$ transformed to meet the assumption of homogeneity of variance [66].

Temporal variation in isotopic signatures was examined using multivariate analysis of variance (MANOVA) and the same suite of three isotopes. Assumptions of MANOVA are the same as the DFA [67]. Pillai's trace was used as the test statistic to detect annual differences in isotopic signatures since it is robust to violations of the homogeneity of covariance assumption [66]. Eigenvalues and canonical correlations for each axis were reported for canonical axes that contributed at least $10 \%$ of the variation in the DF.

Isotopic analyses that involved models examining year and site effects were compared by a mixed linear model in Proc Mixed in SAS (version 9.1.3). Models were ranked by their Akaike information criterion for small sample size differences $\left(\triangle \mathrm{AIC} \mathrm{C}_{\mathrm{c}}\right)$ relative to the best model in the set. Akaike weights $\left(w_{i}\right)$ quantify the probability that a particular model is the best model in the set given the data and the model set. Model weights were calculated from the equation given in Turkheimer et al. [68]. Strontium isotopic ratios were compared among sites and years using box plots in SigmaPlot ${ }^{\circledR} 12$ (Systat Software Inc., San Jose, CA, USA).

\section{Results}

From 2005-2007, we collected 141 age-0 northern pike from Lake Catamount and 96 from Stagecoach Reservoir. Strontium isotopic concentrations in Lake Catamount were not stable, with increasing concentrations from 2005 (mean $\pm 95 \%$ CI; $548 \pm 52$ ppm), 2006 (893 $\pm 46 \mathrm{ppm})$, and 2007 (1216 $\pm 53 \mathrm{ppm}$ ) (Figure 2). Strontium isotopic signatures were more stable in Stagecoach Reservoir, though the concentration did increase in 2007 (896 \pm 28 ppm) compared to 2005 (750 \pm 34 ppm) and 2006 (787 \pm 44 ppm). Barium signatures in Stagecoach Reservoir were fairly stable, but the concentration decreased in 2007 (24 \pm 3 ppm) compared to 2005 ( $29 \pm 3$ ppm) and 2006 (33 \pm 4 ppm). Lake Catamount barium concentration was highest in 2006 (48 \pm 4 ppm), versus 2005 (38 \pm 3 ppm) and 2007 (41 \pm 3 ppm). Manganese isotopic concentrations were similar in Stagecoach Reservoir, though concentration and variation increased each year from 2005 (31 \pm 4 ppm) to 2006 (40 $\pm 6 \mathrm{ppm})$ and 2007 (59 $\pm 17 \mathrm{ppm})$. Manganese isotopic concentration in Lake Catamount was similar in 2005 (55 \pm 12 ppm) and 2006 (54 \pm 8 ppm), but it increased in 2007 (123 $\pm 15 \mathrm{ppm})$.

The isotopic concentration classification accuracy averaged $86 \%$ with a range of 73-100\% (Figure 3). Multivariate discriminant function analysis indicated that strontium had the highest canonical correlations in 2005 and 2007 and barium had the highest in 2006 (Table 1). All canonical axes were significant $(p<0.001)$. MANOVA using strontium, barium, and manganese indicated signatures within sites varied among years (Pillai's trace statistic; $p<0.01$ ), with the exception of Stagecoach Reservoir between 2005 and 2006 $(p=0.11)$. 

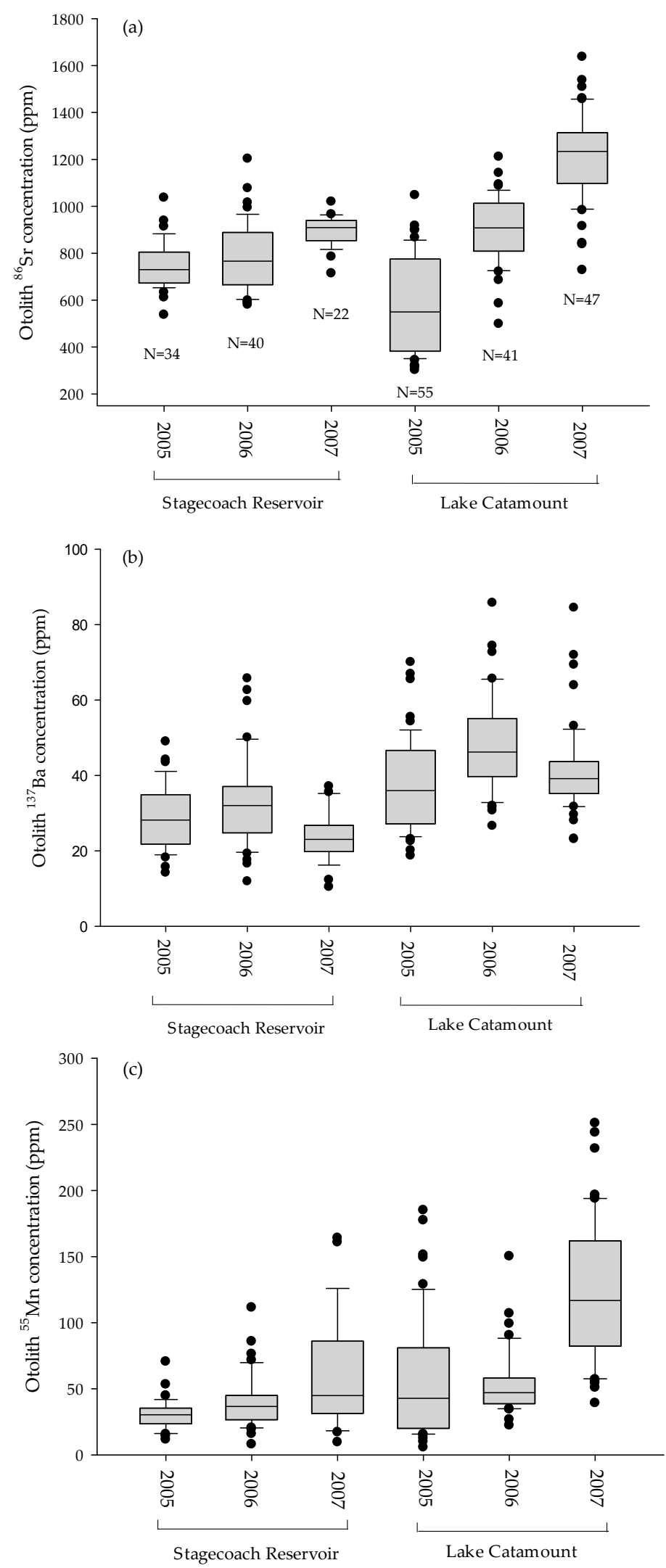

Location and year

Figure 2. Box plots of northern pike otolith isotopic concentrations ((a) ${ }^{86} \mathrm{Sr}$, (b) ${ }^{137} \mathrm{Ba}$, and (c) $\left.{ }^{55} \mathrm{Mn}\right)$ collected from Lake Catamount and Stagecoach Reservoir, Colorado, USA, from 2005-2007. 

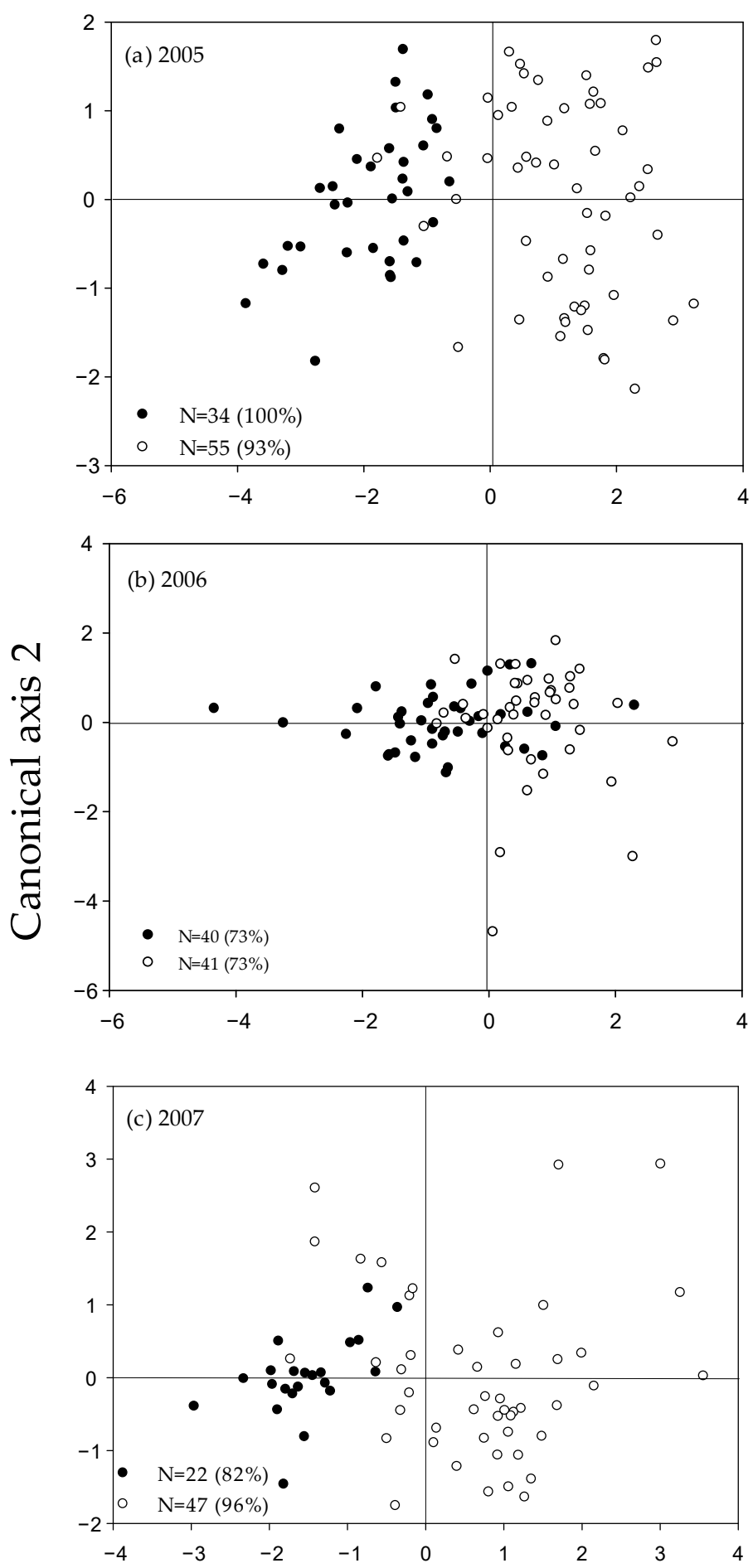

Canonical axis 1

Figure 3. Canonical correlations of age-0 northern pike otolith isotopic concentrations collected in (a) 2005, (b) 2006, and (c) 2007 from Stagecoach Reservoir (closed circles) and Lake Catamount (open circles), Colorado, USA. The legend indicates sample size and correct classification percent for each year. Isotopic concentrations analyzed included barium $\left({ }^{137} \mathrm{Ba}\right)$, strontium $\left({ }^{86} \mathrm{Sr}\right)$, and manganese ( $\left.{ }^{55} \mathrm{Mn}\right)$. 
Table 1. Results of multivariate discriminant function analysis of isotopic concentrations of strontium $\left({ }^{86} \mathrm{Sr}\right)$, barium $\left({ }^{137} \mathrm{Ba}\right)$, and manganese $\left({ }^{55} \mathrm{Mn}\right)$ from northern pike otoliths collected in the Yampa River Basin, Colorado, USA. Only canonical axes explaining greater than $10 \%$ of the variation were included. All canonical axes shown were significant $(p<0.001)$. The element with the highest correlation for each analysis is shown in bold.

\begin{tabular}{ccccc}
\hline & & \multicolumn{3}{c}{ Canonical Correlations } \\
\hline Year & Eigenvalue & ${ }^{\mathbf{8 6}} \mathbf{S r}$ & ${ }^{\mathbf{1 3 7}} \mathbf{B a}$ & ${ }^{55} \mathbf{M n}$ \\
\hline 2005 & 2.24 & $\mathbf{0 . 5 5}$ & -0.46 & -0.28 \\
2006 & 0.50 & 0.37 & $\mathbf{0 . 7 6}$ & 0.66 \\
2007 & 1.11 & $\mathbf{0 . 8 1}$ & 0.54 & 0.34 \\
\hline
\end{tabular}

Strontium isotopic ratios $\left({ }^{87} \mathrm{Sr} /{ }^{86} \mathrm{Sr}\right)$ ranged from $0.7091-0.7122$ and were relatively stable among years (Figure 4). The ratios did increase slightly from 2005 to 2007, when the mean increased from 0.7109 to 0.7111 and 0.7113 , respectively. However, this small increase in isotopic ratio is relatively stable compared to the isotopic concentrations, and its value did not approach the value for the Lake Catamount signature. The top model comparing ${ }^{87} \mathrm{Sr} /{ }^{86} \mathrm{Sr}$ ratios (no isotopic concentration data were included in this analysis) included an intercept, site, year, and the interaction site by year (Table 2). The top three models accounted for all of the model weight and no other models were supported. Site was included in all weighted models, indicating that the two reservoirs differ in terms of strontium isotopic ratios. The model that contained only year had no weight, which indicates that the signatures are temporally stable. The year and site interaction indicates what little variation there is in the year covariate, and the effect is not consistently positive or negative. Box plots of the ${ }^{87} \mathrm{Sr} /{ }^{86} \mathrm{Sr}$ ratio from Stagecoach Reservoir and Lake Catamount indicate that these signatures are consistent within a site, different between sites, and relatively stable across years (Figure 4$)$. Therefore, isotopic ratios $\left({ }^{87} \mathrm{Sr} /{ }^{86} \mathrm{Sr}\right.$ ratios) differed between the two investigated reservoirs and were relatively stable among years.

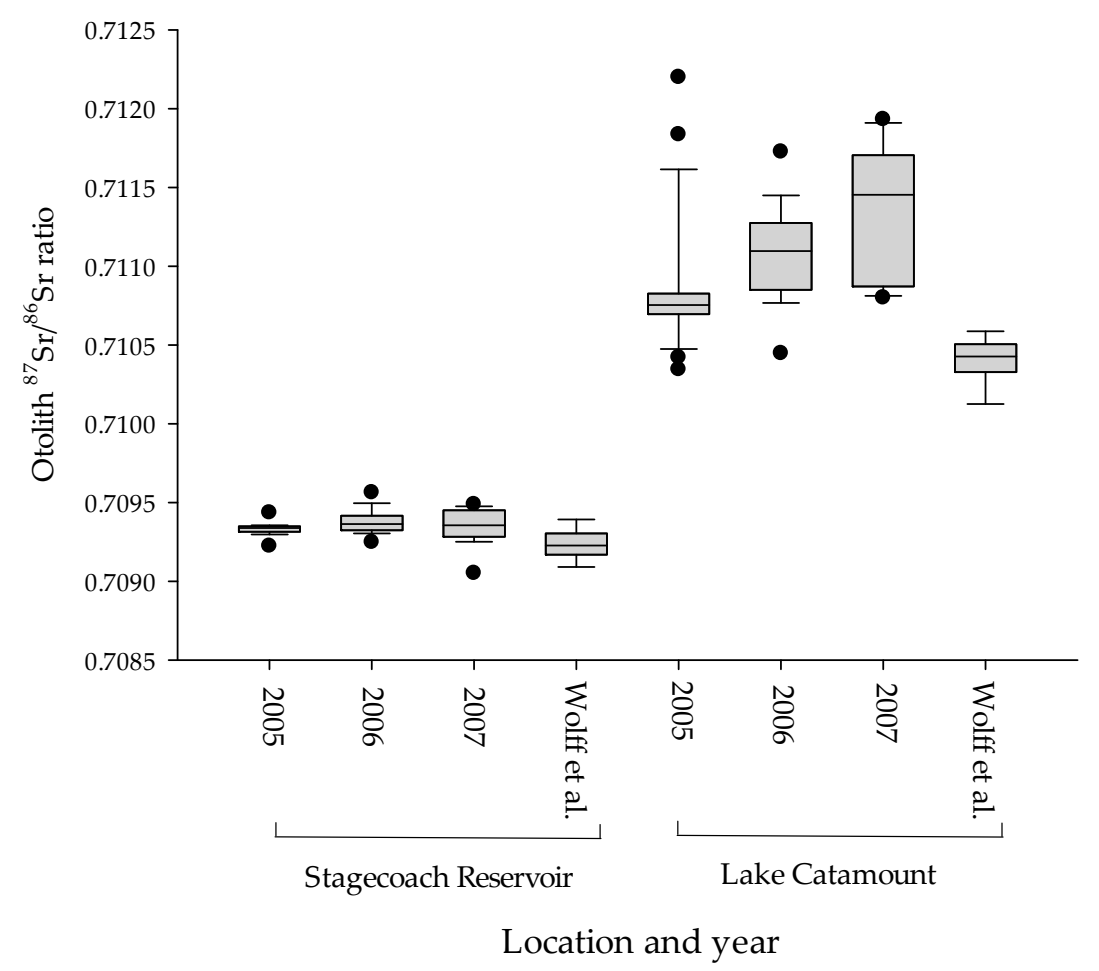

Figure 4. Box plots of the ${ }^{87} \mathrm{Sr} /{ }^{86} \mathrm{Sr}$ ratio from northern pike otoliths collected from Lake Catamount and Stagecoach Reservoir, Colorado, USA from 2005-2007. Wolff et al.'s [34] data were collected as part of a broader spatial scale studyand included multiple age classes of fish. 
Table 2. Results of model selection using Akaike's information criterion (AIC) for five models examining the effects of site, year, and interaction between site and year on ${ }^{87} \mathrm{Sr} /{ }^{86} \mathrm{Sr}$ ratios from northern pike in the Yampa River, Colorado, USA.

\begin{tabular}{cccc}
\hline Model & $\mathbf{A I C}_{\mathbf{c}}$ & $\boldsymbol{\Delta} \mathbf{A I C}_{\mathbf{c}}$ & $\boldsymbol{w}_{\boldsymbol{i}}$ \\
\hline Intercept, site, year, and site x year & -2041.8 & 0 & 0.823 \\
Intercept, site, year & -2038.2 & 3.6 & 0.136 \\
Intercept and site & -2035.8 & 6.0 & 0.041 \\
Intercept and year & -1315.0 & 726.8 & 0.000 \\
Intercept & -1299.2 & 742.6 & 0.000 \\
\hline
\end{tabular}

\section{Discussion}

The strontium isotopic ratios $\left({ }^{87} \mathrm{Sr} /{ }^{86} \mathrm{Sr}\right)$ differed between the two investigated reservoirs and were relatively stable among years. This indicates that strontium ratios can be used as a reliable signature for the reservoirs in the study area. Isotopic concentrations varied annually and between sites. This indicates that if isotopic concentrations were to be used to classify northern pike origins, a bank of isotopic signatures from each reservoir would need to be collected annually. However, this would be an expensive management option that may not be feasible. Therefore, future examination of northern pike and other invasive species origins and movement between the investigated reservoirs would be best served to only focus on strontium isotopic ratios since they are spatially distinct and temporally stable $[33,34,61]$. Studies in other areas, including other areas of the Yampa River system beyond the investigated reservoirs, may examine annual variation in isotopic signatures if they are attempting to use them to estimate natal origins.

The high classification rates of fish between Stagecoach Reservoir and Lake Catamount may be surprising due to the relatively short distance between the two reservoirs. An explanation for the high classification rates is the underlying geology of the tributaries (Morrison Creek, Service Creek, and Green Creek) that flow from the east into the Yampa River between Stagecoach and Lake Catamount, as well as Harrison Creek, which flows directly into Lake Catamount (Figure 1). These high gradient tributaries flow over Precambrian granite rocks of $1700 \mathrm{Ma}$, compared to the lower gradient tributaries that flow into Stagecoach Reservoir over mostly Cretaceous Mancos Shale (Figure 1b). Even with the relatively short distance between sites, these differences in underlying geology appear to be driving the differences in otolith elemental and isotopic signatures. Using geologic maps to identify differences in geologic characteristics underlying tributaries may be helpful to determine the efficacy of applying otolith microchemistry as a useful tool to discriminate between sites.

Our classification rates using otolith isotopic composition to estimate natal areas of northern pike from Stagecoach Reservoir to Lake Catamount over three years (86\%) compare well with other published microchemistry studies in freshwater. Wells et al. [69] had classification rates of $100 \%$ for cutthroat trout (Oncorhynchus clarkii lewisi), and other studies achieved overall success rates of $86 \%$ for yellow perch (Perca flavescens) [70], 71\% for Sacramento splittail (Pogonichthys macrolepidotus) [52], 45\% for lake herring (Coregonus artedi) [71], and 75-93\% for walleye (Sander vitreus) [72]. In addition to natal area discrimination, otolith microchemistry has been used to distinguish between walleye habitat types $(87 \%)$ and individual sites (75\%) [72]. Many of these studies collected age-0 fish only in one year and did not examine temporal variation in otolith isotopic signatures. Consistency in results among Wolff et al. [34] and our study, which had greater sample sizes collected over three years, provides confidence in the use of ${ }^{87} \mathrm{Sr} /{ }^{86} \mathrm{Sr}$ isotope ratios to evaluate sources of northern pike recruitment from these reservoirs (Figure 4).

The goal of this study was to illustrate the efficacy of using otolith microchemistry to estimate northern pike natal origins in two reservoirs that are in close proximity and hydrologically linked. Both isotopic concentrations $\left({ }^{137} \mathrm{Ba},{ }^{86} \mathrm{Sr}\right.$, and $\left.{ }^{55} \mathrm{Mn}\right)$ and isotopic ratios $\left({ }^{87} \mathrm{Sr} /{ }^{86} \mathrm{Sr}\right)$ were different between the reservoirs, but only the strontium isotopic ratios were stable among years. To identify multiple age classes of northern pike using 
isotopic concentrations, it would be necessary to collect age- 0 northern pike annually to build a bank of isotopic signatures, which is resource intensive.

The long-term efficacy of northern pike control efforts in Lake Catamount depends on the rate of northern pike movement from Stagecoach Reservoir to Lake Catamount. If reinvasion rates are low, then a large, focused effort to remove northern pike may be effective and control northern pike for many years. However, if reinvasion rates are high, continual control efforts will be necessary to keep northern pike numbers low. A greater understanding of these reinvasion rates will help guide management to the appropriate level of control efforts. Strontium isotopes $\left({ }^{87} \mathrm{Sr} /{ }^{86} \mathrm{Sr}\right)$ are different between sites and stable among years. Future studies interested in using otolith microchemistry may examine geological maps of their area of interest. If differences are identified in underlying geology between the study sites, especially in tributaries between sites, then $\left({ }^{87} \mathrm{Sr} /{ }^{86} \mathrm{Sr}\right)$ measurements may be useful for determining natal areas of fishes in those systems despite being in relatively close proximity.

Supplementary Materials: The following are available online at https:/ / www.mdpi.com/article/10 $.3390 /$ fishes6040067/s1.

Author Contributions: Conceptualization, R.M.F., D.L.W. and B.M.J.; methodology, R.M.F., D.L.W. and B.M.J.; software, R.M.F.; validation, R.M.F. and D.L.W.; formal analysis, R.M.F.; investigation, R.M.F. and D.L.W.; resources, D.L.W.; data curation, R.M.F.; writing-original draft preparation, R.M.F.; writing-review and editing, D.L.W. and B.M.J.; visualization, R.M.F., D.L.W. and B.M.J.; supervision, D.L.W.; project administration, D.L.W.; funding acquisition, D.L.W. All authors have read and agreed to the published version of the manuscript.

Funding: This research was funded by Colorado Parks and Wildlife through the Colorado Cooperative Fish and Wildlife Research Unit, task order 0603 EB CDOW, and by the Recovery Implementation Program for Endangered Fish Species in the Upper Colorado River Basin, project number 143. The Recovery Program is a joint effort of the U.S. Fish and Wildlife Service, U.S. Bureau of Reclamation, Western Area Power Administration, states of Colorado, Utah, and Wyoming, USA, Upper Basin water users, environmental organizations, the Colorado River Energy Distributors Association, and the National Park Service.

Institutional Review Board Statement: The collection of organisms was conducted in accordance with all applicable laws, guidelines, and regulations, and was covered by the Colorado State University Animal Care and Use Committee (Animal Welfare Assurance Number: A3572-01; protocol number: 104-200A-01) and the State of Colorado (Scientific Collection License: 05-AQ963).

Data Availability Statement: Data were provided as a supplement.

Acknowledgments: We thank Kevin Rogers for reviewing an earlier version of this manuscript, as well as three anonymous reviewers. We thank Grant Wilcox, GIS Group, Colorado Parks and Wildlife for the study area map. Any use of trade, firm, or product names is for descriptive purposes only and does not imply endorsement by the U.S. Government.

Conflicts of Interest: The authors declare no conflict of interest.

\section{References}

1. Leprieur, F.; Brosse, S.; García-Berthou, E.; Oberdorff, T.; Olden, J.D.; Townsend, C.R. Scientific uncertainty and the assessment of risks posed by non-native freshwater fishes. Fish Fish. 2009, 10, 88-97. [CrossRef]

2. Vitule, J.R.S.; Freire, C.A.; Simberloff, D. Introduction of non-native freshwater fish can certainly be bad. Fish Fish. 2009, 10, 98-108. [CrossRef]

3. Gallardo, B.; Clavero, M.; Sánchez, M.I.; Vilá, M. Global ecological impacts of invasive species in aquatic ecosystems. Glob. Chang. Biol. 2016, 22, 151-163. [CrossRef]

4. Vander Zanden, M.J.; Lapointe, N.W.R.; Marchetti, M.P. Non-indigenous fishes and their role in freshwater imperilment. In Conservation of Freshwater Fishes; Closs, G.P., Krkosek, M., Olden, J.D., Eds.; Cambridge University Press: Cambridge, UK, 2016; Volume 1, pp. 238-269.

5. Rahel, F.J.; Smith, M.A. Pathways of unauthorized fish introductions and types of management responses. Hydrobiologia 2018, 817, 41-56. [CrossRef]

6. Britton, J.R.; Gozlan, R.E.; Copp, G.H. Managing non-native fish in the environment. Fish Fish. 2011, 12, 256-274. [CrossRef] 
7. Cucherosset, J.; Olden, J.D. Ecological impacts of non-native freshwater fishes. Fisheries 2011, 36, 215-230. [CrossRef]

8. Bergman, P.K.; Haw, F.; Blankenship, H.L.; Buckley, R.M. Perspectives on design, use, and misuse of fish tags. Fisheries 1992, 17, 20-25. [CrossRef]

9. Pierce, R.B.; Tomcko, C.M. Tag loss and handling mortality for northern pike marked with plastic anchor tags. N. Am. J. Fish. Manag. 1993, 13, 613-615. [CrossRef]

10. Campana, S.E.; Chouinard, G.A.; Janson, J.M.; Frechet, A.; Brattey, J. Otolith elemental fingerprints as biological tracers of fish stocks. Fish. Res. 2000, 46, 343-357. [CrossRef]

11. Schaffler, J.J.; Winkelman, D.L. Temporal and spatial variability in otolith trace-element signatures of juvenile striped bass from spawning locations in Lake Texoma, Oklahoma-Texas. Trans. Am. Fish. Soc. 2008, 137, 818-829. [CrossRef]

12. Schaffler, J.J.; Young, S.P.; Herrington, S.; Ingram, T.; Tannehill, J. Otolith chemistry to determine within-river origins of Alabama Shad in the Apalachicola-Chattahoochee-Flint River basin. Trans. Am. Fish. Soc. 2015, 144, 1-10. [CrossRef]

13. Schulz-Mirbach, T.; Ladich, F.; Plath, M.; Heß, M. Enigmatic ear stones: What we know about the functional role and evolution of fish otoliths. Biol. Rev. 2019, 94, 457-482. [CrossRef]

14. Hüssy, K.; Limburg, K.E.; de Pontual, H.; Thomas, O.R.B.; Cook, P.K.; Heimbrand, Y.; Blass, M.; Sturrock, A.M. Trace element patterns in otoliths: The role of biomineralization. Rev. Fish. Sci. Aquac. 2020, 1-32. [CrossRef]

15. Campana, S.E.; Neilson, J.D. Microstructure of fish otoliths. Can. J. Fish. Aquat. Sci. 1985, 42, 1014-1032. [CrossRef]

16. Bestgen, K.R.; Bundy, J.M. Environmental factors affect daily increment deposition and otolith growth in young Colorado Squawfish. Trans. Am. Fish. Soc. 1998, 127, 105-117. [CrossRef]

17. Haworth, M.R.; Bestgen, K.R. Daily increment validation and effects of streamflow variability and water temperature on growth of age-0 Flathead Chub. N. Am. J. Fish. Manag. 2016, 36, 744-753. [CrossRef]

18. Pacheco, C.; Bustamante, C.; Araya, M. Mass-effect: Understanding the relationship between age and otolith weight in fishes. Fish Fish. 2021, 22, 623-633. [CrossRef]

19. D’Iglio, C.; Albano, M.; Famulari, S.; Savoca, S.; Panarello, G.; Di Paola, D.; Perdichizzi, A.; Rinelli, P.; Lanteri, G.; Spanò, N.; et al. Intra-and interspecific variability among congeneric Pagellus otoliths. Sci. Rep. 2021, 11, 1-15. [CrossRef]

20. Torres, G.J.; Lombarte, A.; Morales-Nin, B. Sagittal otolith size and shape variability to identify geographical intraspecific differences in three species of the genus Merluccius. J. Mar. Biol. Assoc. UK 2000, 80, 333-342. [CrossRef]

21. Campana, S.E. Chemistry and composition of fish otoliths: Pathways, mechanisms and applications. Mar. Ecol.-Prog. Ser. 1999, 188, 263-297. [CrossRef]

22. Carlson, K.A.; Bailey, P.E.; Fincel, M.J.; Graeb, B.D.S. Otoliths as elemental tracers of walleye environmental history: Insights for interjurisdictional fisheries management. Lake Reserv. Manag. 2016, 32, 329-340. [CrossRef]

23. Carlson, K.A.; Fincel, M.J.; Graeb, B.D.S. Otolith microchemistry reveals natal origins of walleyes in Missouri River reservoirs. N. Am. J. Fish. Manag. 2016, 36, 341-350. [CrossRef]

24. Avigliano, E.; Pisonero, J.; Sánchez, S.; Dománico, A.; Volpedo, A.V. Estimating contributions from nursery areas to fish stocks in freshwater systems using otolith fingerprints: The case of the streaked prochilod in the La Plata Basin (South American). River Res. Appl. 2018, 34, 863-872. [CrossRef]

25. Lazartigues, A.; Girard, C.; Brodeur, P.; Lecomte, F.; Mingelbeir, M.; Sirois, P. Otolith microchemistry to identify sources of larval yellow perch in a fluvial lake: An approach towards freshwater fish management. Can. J. Fish. Aquat. Sci. 2018, 75, $474-487$. [CrossRef]

26. Maguffee, A.C.; Reilly, R.; Clark, R.; Jones, M.L. Examining the potential of otolith chemistry to determine natal origins of wild Lake Michigan Chinook salmon. Can. J. Fish. Aquat. Sci. 2019, 76, 2035-2044. [CrossRef]

27. David, B.O.; Jarvis, M.; Özkundakci, D.; Collier, K.J.; Hicks, A.D.; Reid, M. To sea or not to sea? Multiple lines of evidence reveal the contribution of non-diadromous recruitment for supporting endemic fish populations within New Zealand's longest river. Aquat. Conserv. 2018, 29, 1409-1423. [CrossRef]

28. Arai, T.; Taha, H.; Amalina, R.; Iizuka, Y.; Chang, C. Anadromy and heterogeneous population of tropical shad Tenualosa ilisha in Malaysia, as revealed by otolith microchemistry and molecular evidence. J. Fish. Biol. 2019, 95, 1506-1511. [CrossRef] [PubMed]

29. Santos, R.O.; Schinbeckler, R.; Viadero, N.; Larkin, M.F.; Rennert, J.J.; Shenker, J.M.; Rehage, J.S. Linking bonefish (Albula vulpes) populations to nearshore estuarine habitats using an otolith microchemistry approach. Environ. Biol. Fish. 2019, 102, 267-283. [CrossRef]

30. Perrion, M.A.; Kaemingk, M.A.; Koupal, K.D.; Schoenebeck, C.W.; Bickford, N.A. Use of otolith chemistry to assess recruitment of a white bass fishery in a Nebraska reservoir. Lake Reserv. Manag. 2020, 36, 64-74. [CrossRef]

31. Gibson-Reneimer, D.K.; Johnson, B.M.; Martinez, P.J.; Winkelman, D.L.; Koenig, A.E.; Woodhead, J.D. Elemental signatures in otoliths of hatchery rainbow trout (Oncorhynchus mykiss): Distinctiveness and utility for detecting origins and movement. Can. J. Fish. Aquat. Sci. 2009, 66, 513-524. [CrossRef]

32. Wolff, B.A.; Johnson, B.M.; Landress, C.M. Classification of hatchery and wild fish using natural geochemical signatures in otoliths, fin rays, and scales of an endangered catostomid. Can. J. Fish. Aquat. Sci. 2013, 70, 1775-1784. [CrossRef]

33. Ciepiela, L.R.; Walters, A.W. Life-history variation of two inland salmonids revealed through otolith microchemistry analysis. Can. J. Fish. Aquat. Sci. 2019, 76, 1971-1981. [CrossRef]

34. Wolff, B.A.; Johnson, B.M.; Breton, A.R.; Martinez, P.J.; Winkelman, D.L. Origins of invasive piscivores determined from the strontium isotope ratio $\left({ }^{87} \mathrm{Sr} /{ }^{86} \mathrm{Sr}\right)$ of otoliths. Can. J. Fish. Aquat. Sci. 2012, 69, 724-739. [CrossRef] 
35. Thorrold, S.R.; Shuttleworth, S. In situ analysis of trace elements and isotope ratios in fish otoliths using laser ablation sector field inductively coupled plasma mass spectrometry. Can. J. Fish. Aquat. Sci. 2000, 57, 1232-1242. [CrossRef]

36. Ranaldi, M.M.; Gagnon, M.M. Zinc incorporation in the otoliths of juvenile pink snapper (Pagrus auratus Forster): The influence of dietary versus waterborne sources. J. Exp. Mar. Biol. Ecol. 2008, 360, 56-62. [CrossRef]

37. Gillanders, B.M. Temporal and spatial variability in elemental composition of otoliths: Implications for determining stock identity and connectivity of populations. Can. J. Fish. Aquat. Sci. 2002, 59, 669-679. [CrossRef]

38. Ciepiela, L.R.; Walters, A.W. Quantifying ${ }^{87} \mathrm{Sr} /{ }^{86} \mathrm{Sr}$ temporal stability and spatial heterogeneity for use in tracking fish movement. Can. J. Fish. Aquat. Sci. 2019, 76, 928-936. [CrossRef]

39. Elsdon, T.S.; Gillanders, B.M. Interactive effects of temperature and salinity on otolith microchemistry: Challenges for determining environmental histories of fish. Can. J. Fish. Aquat. Sci. 2002, 59, 1796-1808. [CrossRef]

40. Sturrock, A.M.; Trueman, C.N.; Milton, J.A.; Waring, C.P.; Cooper, M.J.; Hunter, E. Physiological influences can outweigh environmental signals in otolith microchemistry research. Mar. Ecol.-Prog. Ser. 2014, 500, 245-264. [CrossRef]

41. Tanner, S.E.; Reis-Santos, P.; Cabral, H.N. Otolith chemistry in stock delineation: A brief overview, current challenges and future prospects. Fish. Res. 2016, 173, 206-213. [CrossRef]

42. Nazir, A.; Khan, M.A. Using otoliths for fish stock discrimination: Status and challenges. Acta Ichthyol. Piscat. 2021, 51, 199-218. [CrossRef]

43. Aguilar, A.; Banks, J.D.; Levine, K.F.; Wayne, R.K. Population genetics of northern pike (Esox lucius) introduced into Lake Davis, California. Can. J. Fish. Aquat. Sci. 2005, 62, 1589-1599. [CrossRef]

44. Muhlfeld, C.C.; Bennett, D.H.; Steinhorst, R.K.; Marotz, B.; Boyer, M. Using bioenergetics modeling to estimate consumption of native juvenile salmonids by nonnative northern pike in the Upper Flathead River system, Montana. N. Am. J. Fish. Manag. 2008, 28, 636-648. [CrossRef]

45. Dunker, K.; Massengill, R.; Bradley, P.; Jacobson, C.; Swenson, N.; Wizik, A.; DeCino, R. A decade in review: Alaska's adaptive management of an invasive apex predator. Fishes 2020, 5, 12. [CrossRef]

46. Nesler, T.P. Interactions between Endangered Fishes and Introduced Gamefishes in the Yampa River, Colorado, 1987-1991; Colorado Division of Wildlife: Fort Collins, CO, USA, 1995.

47. Zelasko, K.A.; Bestgen, K.R.; Hawkins, J.A.; White, G.C. Evaluation of long-term predator removal program: Abundance and population dynamics of invasive northern pike in the Yampa River, Colorado. Trans. Am. Fish. Soc. 2016, 145, 1153-1170. [CrossRef]

48. Johnson, B.M.; Martinez, P.J.; Hawkins, J.A.; Bestgen, K.R. Ranking predatory threat by nonnative fishes in the Yampa River, Colorado, via bioenergetics modeling. N. Am. J. Fish. Manag. 2008, 28, 1941-1953. [CrossRef]

49. Rogers, K.B.; Atkinson, B.F.; Orabutt, D.E. Catamount Reservoir: Fish Community Summary; Colorado Division of Wildlife: Steamboat Springs, CO, USA, 2005.

50. Bauch, N.J.; Moore, J.L.; Schaffrath, K.R.; Dupree, J.A. Water-Quality Assessment and Macroinvertebrate Data for the Upper Yampa River Watershed, Colorado, 1975 through 2009; U.S. Geological Survey Scientific Investigations Report 2012-5214; U.S. Geological Survey: Reston, VA, USA, 2012.

51. Walther, B.D.; Thorrold, S.R. Water, not food, contributes the majority of strontium and barium deposited in the otoliths of a marine fish. Mar. Ecol.-Prog. Ser. 2006, 311, 125-130. [CrossRef]

52. Feyrer, F.; Hobbs, J.; Baerwald, M.; Sommer, T.; Yin, Q.; Clark, K.; May, B.; Bennett, W. Otolith microchemistry provides information complementary to microsatellite DNA for a migratory fish. Trans. Am. Fish. Soc. 2007, 136, 469-476. [CrossRef]

53. Stoeser, D.B.; Green, G.N.; Morath, L.C.; Heran, W.D.; Wilson, A.B.; Moore, D.W.; Van Gosen, B.S. Preliminary integrated geologic map databases for the United States, Central States-Montana, Wyoming, Colorado, New Mexico, North Dakota, South Dakota, Nebraska, Kansas, Oklahoma, Texas, Iowa, Missouri, Arkansas, and Louisiana: U.S. Geological Survey Open-File Report 2005-1351, version 1.2. 2005; updated December 2007. Available online: http://pubs.usgs.gov/of/2005/1351/ (accessed on 1 June 2012).

54. Tyus, H.M.; Beard, J.M. Esox lucius (Esocidae) and Stizostedium vitreum (Percidae) in the Green River basin, Colorado and Utah Great Basin Nat. 1990, 50, 33-39.

55. Martinez, A.; Felt, B.; Dewhirst, J.; Eyre, T.; Martin, L. FY 2020 Annual Report Project Number C-20; Upper Colorado River Endangered Fish Recovery Program: Meeker, CO, USA, 2020.

56. Orabutt, D.E. Northern Pike in Selected Colorado Trout Reservoirs. Master's Thesis, Colorado State University, Fort Collins, CO, USA, 2006.

57. Hill, C.G. Dynamics of Northern Pike Spawning and Nursery Habitat in the Yampa River, Colorado. Master's Thesis, Colorado State University, Fort Collins, CO, USA, 2004.

58. Martin, L.M. Middle Yampa River Northern Pike Removal and Evaluation \#98A-1, Colorado River Recovery Program FY 2005 Annual Project Report; Colorado Division of Wildlife: Fort Collins, CO, USA, 2005.

59. Craig, J.F. Pike: Biology and Exploitation; Chapman \& Hall: London, UK, 1996.

60. Rogers, K.B. (Colorado Parks and Wildlife, Steamboat Springs, CO, USA). Personal communication, 2001.

61. Whitledge, G.W.; Johnson, B.M.; Martinez, P.J.; Martinez, A.M. Sources of nonnative centrarchids in the Upper Colorado River revealed by stable isotope and microchemical analyses of otoliths. Trans. Am. Fish. Soc. 2007, 1036, 1263-1275. [CrossRef] 
62. Wilson, S.A.; Ridley, W.I.; Koenig, A.E. Development of sulfide calibration standards for the laser ablation inductively-coupled plasma mass spectrometry technique. J. Anal. At. Spectrom. 2002, 17, 406-409. [CrossRef]

63. Longerich, H.P.; Jackson, S.E.; Gunther, D. Laser ablation-inductively coupled plasma-mass spectrometric transient signal data acquisition and analyte concentration calculation. J. Anal. At. Spectrom. 1996, 11, 899-904. [CrossRef]

64. Pracheil, B.M.; George, R.; Chakoumakos, B.C. Significance of otolith calcium carbonate crystal structure diversity to microchemistry studies. Rev. Fish. Biol. Fish. 2019, 29, 569-588. [CrossRef]

65. Yoshinaga, J.; Nakama, A.; Morita, M.; Edmonds, J.S. Fish otolith reference material for quality assurance of chemical analyses. Mar. Chem. 2000, 69, 91-97. [CrossRef]

66. Tabachnick, B.G.; Fidell, L.S. Using Multivariate Statistics, 5th ed.; Allyn and Bacon: Boston, MA, USA, 2007.

67. Quinn, G.P.; Keogh, M.J. Experimental Design and Data Analysis for Biologists; University Press: New York, NY, USA, 2002.

68. Turkheimer, F.E.; Hinz, R.; Cunningham, V.J. On the undecidability among kinetic models: From model selection to model averaging. J. Cereb. Blood Flow Metab. 2003, 23, 490-498. [CrossRef] [PubMed]

69. Wells, B.K.; Reiman, B.E.; Clayton, J.L.; Horan, D.L.; Jones, C.M. Relationship between water, otolith and scale chemistries of westslope cutthroat trout from Coeur d'Alene River, Idaho: The potential application of hard-part chemistry to describe movements in freshwater. Trans. Am. Fish. Soc. 2003, 132, 409-424. [CrossRef]

70. Brazner, J.C.; Campana, S.E.; Tanner, D.K.; Schram, S.T. Habitat fingerprints from Lake Superior coastal wetlands derived from elemental analysis of yellow perch otoliths. Trans. Am. Fish. Soc. 2004, 133, 692-704. [CrossRef]

71. Bronte, C.R.; Hesselberg, R.J.; Shoesmith, J.A.; Hoff, M.H. Discrimination among spawning concentration of Lake Superior lake herring based on trace element profiles in sagittae. Trans. Am. Fish. Soc. 1996, 125, 852-859. [CrossRef]

72. Carlson, A.K.; Fincel, M.J.; Graeb, B.D.S. Otolith chemistry indicates walleye movement and entrainment in a large serial reservoir system. Fish. Manag. Ecol. 2017, 24, 217-229. [CrossRef] 